\title{
Leptospira fainei sp. nov., isolated from pigs in Australia
}

\author{
P. Perolat, ${ }^{1}$ R. J. Chappel, ${ }^{2}$ B. Adler, ${ }^{3}$ G. Baranton, ${ }^{4}$ D. M. Bulach, ${ }^{3}$ \\ M. L. Billinghurst, ${ }^{2}$ M. Letocart, ${ }^{1}$ F. Merien ${ }^{1}$ and M. S. Serrano ${ }^{3}$
}

Author for correspondence: P. Perolat. Tel: +6872702 80. Fax: +687273390.

e-mail: perolat_pasteur@canl.nc

\begin{abstract}
Pathogenic leptospires can be causative agents of reproductive problems in pigs. Cultures of uteri and kidneys from two pig herds in New South Wales and Victoria (Australia) yielded five strains identified as Leptospira on morphological and cultural grounds. Phenotypic characteristics (growth at 13 and $30{ }^{\circ} \mathrm{C}$, growth in the presence of 8-azaguanine) were intermediate between those of pathogenic and saprophytic leptospires. No crossagglutination was observed with reference antisera representing the 24 pathogenic serogroups and the main saprophytic ones. Antiserum against one of the strains did not agglutinate reference strains representative of any serogroup. This provided evidence of a new serovar, designated hurstbridge. Genomic characterization of the five strains was achieved using five molecular approaches. Mapped restriction site polymorphisms in the rrs (16S rRNA) gene were not related to those of any reference strains. Arbitrarily primed PCR fingerprints suggested clonality of the five strains. The strains all showed an identical and unique PFGE profile. PCR, using primers specific for the rrs gene of pathogenic leptospires, amplified corresponding sequences from the strains. DNA-DNA hybridization (and reciprocal experiments) using the S1 nuclease/TCA method was performed between one of the strains and the reference strains of Leptospira species. The homology ranged from 0 to $36 \%$ (the latter being with Leptospira inadai) thus satisfying the criterion of a new species, Leptospira fainei (type strain BUT 6'). Phylogenetic analysis of 165 rRNA sequences showed that $L$. fainei and $L$. inadai formed a clade separate from the previously recognized 'saprophyte' and 'pathogen' clades.
\end{abstract}

Keywords: Leptospira fainei sp. nov., pigs, phylogenetic analysis, serovar hurstbridge, molecular typing

\section{INTRODUCTION}

Leptospirosis, caused by pathogenic serovars of Leptospira, is a zoonosis of worldwide distribution. For taxonomic purposes, and as an aid to epidemiological studies, the pathogenic leptospires have been subdivided into serovars by agglutination-absorption patterns (4). Related serovars have been placed within 24 recognized serogroups, containing more than 200 serovars (7). Alternative serological typing systems

\footnotetext{
Abbreviations : AP-PCR, arbitrarily primed PCR; MRSP, mapped restriction site polymorphism; SCT, Subcommittee on Taxonomy of Leptospira.

The GenBank accession number for the 16S rRNA sequence of $L$. fainei is
} U60594. based on either monoclonal antibodies or factor analysis give comparable results to conventional serotyping methods $(4,10)$.

Molecular taxonomic studies have greatly improved our knowledge of the diversity of Leptospira. DNADNA hybridization studies $(19,24)$ showed that members of Leptospira interrogans sensu lato were diverse at the DNA level. Subsequently, leptospires were grouped into seven (24) and then eight (19) pathogenic species (Leptospira borgpetersenii, Leptospira inadai, Leptospira interrogans sensu stricto, Leptospira kirschneri, Leptospira meyeri, Leptospira noguchii, Leptospira santarosai and Leptospira weilii) and two saprophytic ones (Leptospira biflexa and Leptospira wolbachii). 
Several molecular techniques can be used as additional typing systems in epidemiological studies, since they identify strain differences at the infraspecific level. These include restriction endonuclease analysis of chromosomal DNA by fixed-field electrophoresis (6) or PFGE (9), RFLPs (25) and ribotyping (16). Nevertheless, the identification of leptospires at the species level remains difficult, as DNA-DNA hybridization is not feasible for routine identification. PCR-based strategies were therefore developed to categorize the new species of Leptospira (18). Mapped restriction site polymorphisms (MRSPs) in PCR-amplified ribosomal genes grouped reference strains in agreement with their DNA relatedness $(17,18)$. Arbitrarily primed PCR (AP-PCR) generates distinctive fingerprints that can be used for molecular epidemiology (17) and to rapidly identify strains at the species level (14).

In 1994, the Victorian Institute of Animal Science (Attwood, Victoria, Australia) isolated five Leptospira strains that did not belong to any known serogroup (3). These strains were isolated from cultures of uteri and kidneys from two pig herds, in Victoria and New South Wales, and were identified as a new serovar named hurstbridge. Examination by conventional phenotyping and molecular typing methods suggested that these strains were identical and represented a new species within the genus Leptospira. This was confirmed by DNA-DNA hybridization experiments, and the name of Leptospira fainei sp. nov. is proposed for this organism. In this paper, we report the antigenic and genetic characterization and phylogenetic position of $L$. faine $i$.

\section{METHODS}

Bacterial strains and reference antisera. All reference strains used were from the WHO Reference Laboratory and Collaborating Centre for Leptospirosis, Institut Pasteur, Paris.

For conventional serotyping, the reference antisera of the 24 pathogenic serogroups (Australis, Autumnalis, Ballum, Bataviae, Canicola, Celledoni, Cynopteri, Djasiman, Grippotyphosa, Hebdomadis, Icterohaemorrhagiae, Javanica, Louisiana, Lyme, Manhao, Mini, Panama, Pomona, Pyrogenes, Ranarum, Sarmin, Sejroe, Shermani and Tarassovi) and of the two main saprophytic serogroups (Codice and Semaranga) were tested according to the recommendations of the Subcommittee on Taxonomy of Leptospira (SCT) (13). A reference antiserum specific for hurstbridge reference strain BUT $6^{\mathrm{T}}$ was produced in New Zealand White rabbits according to SCT recommendations $(7,10)$ and used for reverse agglutination tests (7) against each reference strain representative of the serogroups listed above.

DNA-DNA hybridization experiments involved (i) reference strains representing the eight pathogenic species, (ii) reference strains representing the two saprophytic species and (iii) the type strain of the closely related genus Turneria.

The five hurstbridge strains (BUT $6^{\mathrm{T}}$, BUT 8, BKID 6, BKID 7 and WKID) (3) were included in all the phenotypic and genotypic tests, except in DNA-DNA hybridization, where BUT $6^{\mathrm{T}}$, the designated reference strain of serovar hurstbridge, and WKID were tested. For 16S rRNA gene sequencing, only BUT $6^{\mathrm{T}}$ was studied as the reference strain.

Culture conditions and preparation of DNA. Strains were grown to stationary phase in EMJH medium (5) at $30^{\circ} \mathrm{C}$ with shaking. Chromosomal DNA was extracted using the phenol/chloroform method (2).

\section{Phenotypic characterization}

(i) Light and electron microscopy. Isolates were examined by dark-field microscopy. One strain (BUT $6^{\mathrm{T}}$ ) was examined by transmission electron microscopy using a Philips CM12 STEM electron microscope, employing negative staining with $2 \%$ phosphotungstic acid, at a final magnification of $\times 9450$.

(ii) Growth characteristics. Isolates were tested for characteristics that differentiate pathogenic and saprophytic leptospires $(10,11)$, with $L$. interrogans serovar icterohaemorrhagiae (strain $\mathrm{RGA}^{\mathrm{T}}$ ) and L. biflexa serovar patoc (strain Patoc $\mathrm{I}^{\mathrm{T}}$ ), respectively, as control pathogenic and saprophytic strains. In addition, $L$. inadai serovar lyme (strain $10^{\mathrm{T}}$ ) was included as a leptospiral strain with intermediate growth characteristics (24).

The ability to grow at 13 and $30^{\circ} \mathrm{C}$ was tested in duplicate. Growth was assessed by dark-field microscopy on days 0,3 , 7,10 and 13 . Viability of strains which did not grow at $13^{\circ} \mathrm{C}$ was then confirmed by subculture at $30^{\circ} \mathrm{C}$.

Growth in the presence of 8 -azaguanine $\left(225 \mu \mathrm{g} \mathrm{ml}^{-1}\right)$ was tested (12) in duplicate at $30^{\circ} \mathrm{C}$ and assessed as above. Viability of strains which did not grow in 8-azaguanine was confirmed by simultaneous culture at $30^{\circ} \mathrm{C}$ in $\mathrm{EMJH}$ medium without 8-azaguanine.

(iii) Serotyping. Serotyping of hurstbridge strains was performed according to the recommendations of the SCT (7, 10), using antisera against strain BUT $6^{\mathrm{T}}$ and against reference strains representative of the 26 serogroups listed above.

\section{Genetic characterization}

(i) AP-PCR. AP-PCR was performed with the purified total genomic DNA as described previously $(17,18)$ using the primers KF (5'-CAC GCA CAC GCA CAG AGA-3'), KG (5'-CAC ACG CAC ACG GAA GAA-3'), KN (5'-CCT TGC GCG CAT GTA CAT GG-3'), KpnR (5'-CCA AGT CGA CAT GGC ACR TGT ATA CAT AYG TAA C-3'), KZ (5'-CCC ATG TGT ACG CGT GTG GG-3'), RSP (5'GGA AAC AGC TAT GAC CAT GA-3'), SP (5'-TTG TAA AAC GAC GGC CAG-3'), PR 1 (5'-CGC TAA AAC TAA TAT CAT GA-3') and PR2 (5'-GGA AAC TTA CAC TAA CAG-3'). Briefiy, AP-PCR reactions were cycled twice (GeneAmp 9600; Perkin Elmer) with a low-stringency profile $\left(5 \mathrm{~min}\right.$ at $94^{\circ} \mathrm{C}, 5 \mathrm{~min}$ at $40^{\circ} \mathrm{C}$ and $5 \mathrm{~min}$ at $72^{\circ} \mathrm{C}$ ) followed by 40 cycles at high stringency $\left(1 \mathrm{~min}\right.$ at $94^{\circ} \mathrm{C}$, $1 \mathrm{~min}$ at $60^{\circ} \mathrm{C}$ and $2 \mathrm{~min}$ at $72^{\circ} \mathrm{C}$ ). PCR products were analysed using urea sequencing gels autoradiographed for 2448 h on Kodak X-Omat X-ray film.

(ii) PFGE. Restriction digestion with NotI (Amersham) and PFGE of in situ lysed cells was performed using a Pulsaphor instrument (Pharmacia) with a hexagonal electrode array (9). A program combining three pulse times (30, 60 and $120 \mathrm{~s}$ ) was used and the size of the DNA fragments was estimated by comparison with concatemerized $\lambda$ bacteriophage genomes and Saccharomyces cerevisiae chromosomes (Bio-Rad). 


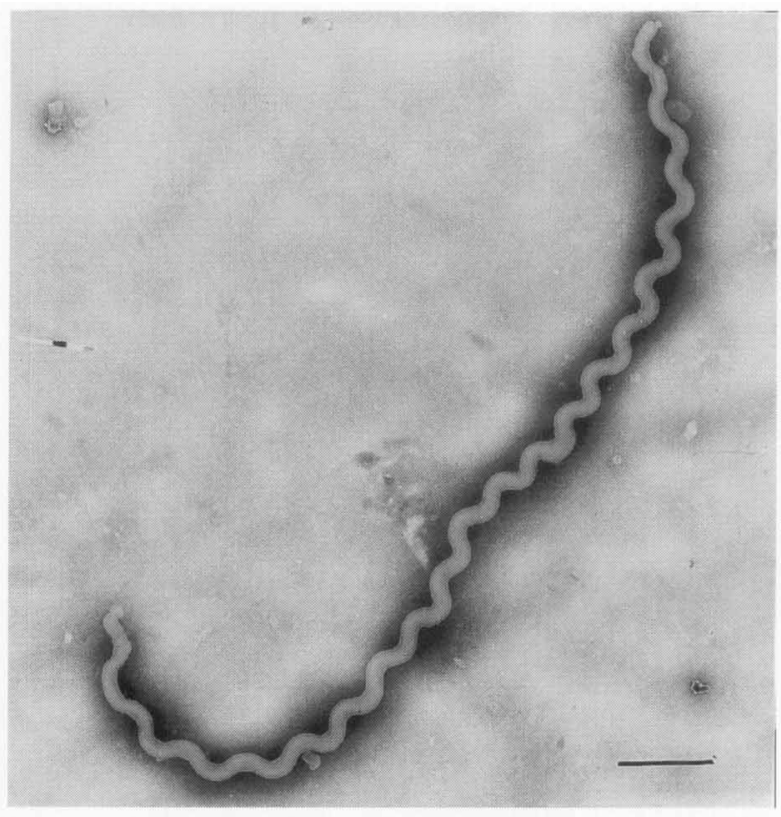

Fig. 1. Electron micrograph of $L$. fainei strain BUT $6^{\top}$. Bar, $1 \mu \mathrm{m}$.

(iii) MRSP. MRSP of the PCR-amplified leptospiral rrs gene was performed as described previously $(17,18)$ using the primers $16 \mathrm{~S}-11$ (5'-GGC TGC AGT CGA CGT TTG ATC CTG GCT CAG-3') and 16S-1507 (5'-CCA GAT CTG AGC TCA AGG AGG TGA TCC AGC-3'). Briefly, restriction enzyme digestions of PCR-amplified leptospiral rrs genes were performed with DdeI, HhaI, NlaIV and TaqI and digests were analysed on polyacrylamide native gels autoradiographed for $24-72 \mathrm{~h}$ on Kodak X-Omat X-ray film.

(iv) DNA-DNA hybridization. In vitro labelling of DNA with tritium-labelled nucleotides and hybridization experiments were performed using the S1 nuclease/TCA method (8) with minor modifications (1). Hybridization reactions were performed in duplicate at an optimal reassociation temperature of $60^{\circ} \mathrm{C}$.

(v) PCR detection of pathogenic signatures on rrs (16S rRNA) genes. Aligning the available rrs gene sequences for Leptospira members (GenBank) by using the vsM program (20), we identified highly conserved regions among pathogenic species that could be used to differentiate saprophytic and pathogenic leptospires. Two corresponding sets of primers including these pathogenic signatures were designed. Set A consisted of primers LP1 (321-371; 5'-GAT TTT TCG GGT AAA GAT TCA TT-3') and a1190 (1573-1549; 5'. TTG CCC TAG ACA TAA AGG CCA-3') and allows the amplification of a $1008 \mathrm{bp}$ fragment. The PCR program was: 1 cycle of $3 \mathrm{~min}$ at $94^{\circ} \mathrm{C}, 1.5 \mathrm{~min}$ at $61^{\circ} \mathrm{C}$ and $2 \mathrm{~min}$ at $72{ }^{\circ} \mathrm{C} ; 29$ cycles of $1 \mathrm{~min}$ at $94{ }^{\circ} \mathrm{C}, 1.5 \mathrm{~min}$ at $61^{\circ} \mathrm{C}$ and $2 \mathrm{~min}$ at $72{ }^{\circ} \mathrm{C}$; 1 cycle of $1 \mathrm{~min}$ at $94^{\circ} \mathrm{C}, 1.5 \mathrm{~min}$ at $61^{\circ} \mathrm{C}$ and 10 min at $72^{\circ} \mathrm{C}$. Set B consisted of primers LU $\left(110-131 ; 5^{\prime}\right.$ CGG CGC GTC TTA AAC ATG-3') and rLP (681-644; $5^{\prime}$ ACC ATC ATC ACA TYG CTG C-3') and its PCR product is of $420 \mathrm{bp}$. The PCR program was the same except that a $56{ }^{\circ} \mathrm{C}$ annealing temperature was used. The specificity of these primers had previously been confirmed on the reference strains of the validated pathogenic and saprophytic

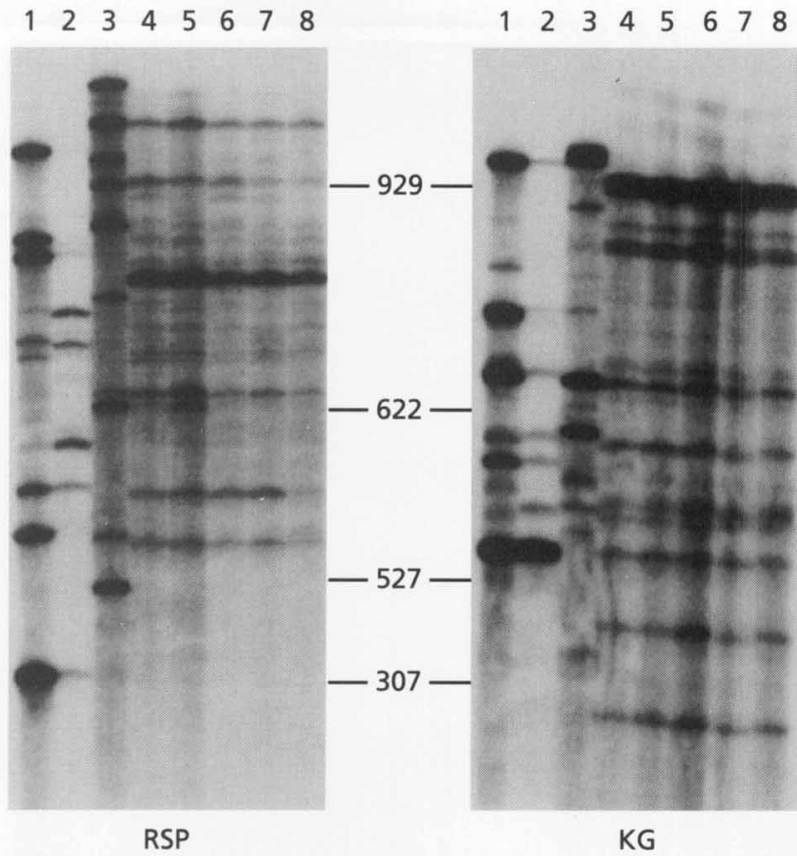

Fig. 2. AP-PCR fingerprints obtained with RSP and KG primers on a $4 \%$ polyacrylamide $/ 50 \%$ urea sequencing gel. Lanes: $1, L$. interrogans serovar icterohaemorrhagiae strain $R_{G A}^{\top} ; 2, L$. interrogans serovar bratislava strain Jez-bratislava; 3 , L. inadai serovar lyme strain $10^{\top} ; 4-8, L$. fainei serovar hurstbridge strains BUT $6^{\top}$, BUT 8, BKID 6, BKID 7 and WKID. Molecular sizes are indicated in bp.

species of Leptospira (P. Perolat \& G. Baranton, unpublished data).

(vi) 165 rRNA gene sequencing. BUT $6^{\mathrm{T}}$ genomic DNA was used as a template for PCR using primers designed to correspond to the sequence of two highly conserved regions within the bacterial 16S rRNA gene. The primers used were $27 \mathrm{~F}\left(5^{\prime}-\right.$ AGA GTT TGA TCM TGG CTC AG-3') and 1492R (5'TAC GGY TAC CTT GTT ACG ACT T-3'). The conditions used for amplification were 30 cycles with the profile $1 \mathrm{~min}$ at $94^{\circ} \mathrm{C}, 1 \mathrm{~min}$ at $50^{\circ} \mathrm{C}$ and $1 \mathrm{~min}$ at $72^{\circ} \mathrm{C}$. Amplified DNA was ligated into pBluescript II KS (Stratagene), which had been first digested with EcoRV and modified using Taq DNA polymerase to add a single $\mathrm{T}$ at the $3^{\prime}$ end (15). Transformants in Escherichia coli DH5 $\alpha$ containing plasmids with inserts of the expected size were selected and one, pLBA471, was selected for further analysis. The nucleotide sequence of the insert was determined using the Prism dye-terminator system (ABI) on an automated sequencer (model 373; ABI).

\section{RESULTS}

\section{Phenotypic characterization}

(i) Light and electron microscopy. The strains showed morphology and motility, under dark-field microscopy, that was characteristic of Leptospira. Fig. 1 shows an electron micrograph of strain BUT $6^{\mathrm{T}}$. Bacterial cells were approximately $12 \mu \mathrm{m}$ long and $0.2 \mu \mathrm{m}$ in diameter, with the typical helical morphology characteristic of Leptospira. 


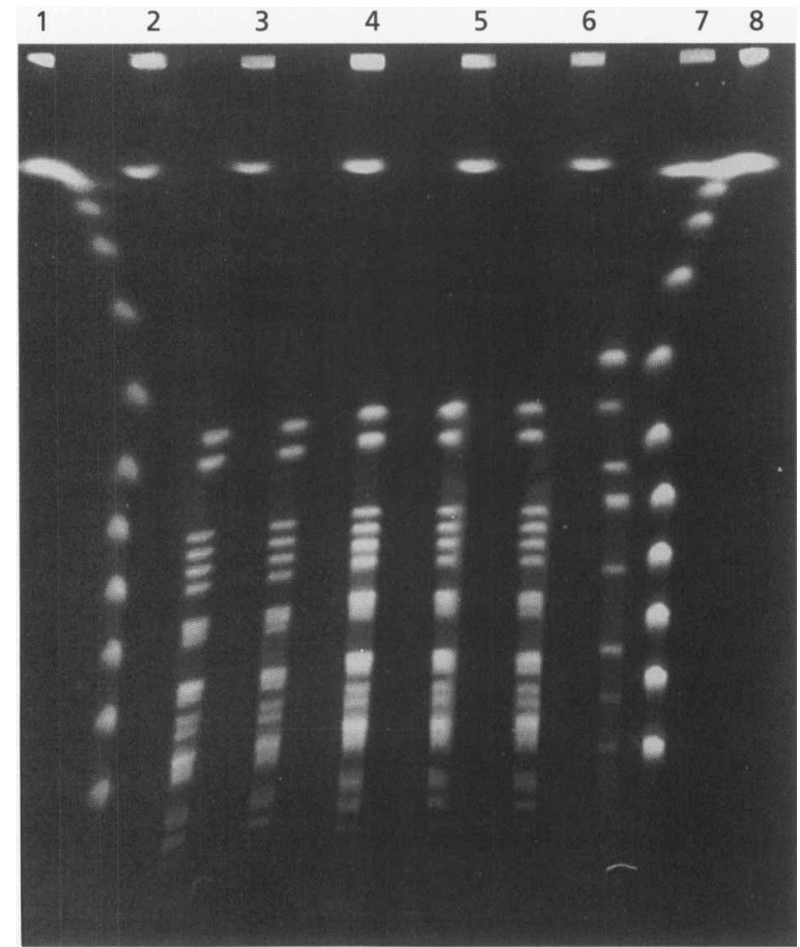

Fig. 3. PFGE of Notl restriction fragments from hurstbridge strains. Lanes 1 and 8 are size markers $(\lambda)$; lanes 2-6 are hurstbridge strain isolates BUT $6^{\top}$, BUT 8, BKID 6, BKID 7 and WKID; lane 7, L. interrogans serovar icterohaemorrhagiae strain RGA $^{\top}$. The digestion products were separated at $150 \mathrm{~V}$ for $40 \mathrm{~h}$ in $1 \%$ agarose $/ 0.5 \times$ Tris-borate-EDTA. The three pulse times were $30 \mathrm{~s} 13 \mathrm{~h} ; 60 \mathrm{~s} 13 \mathrm{~h} ; 120 \mathrm{~s} 14 \mathrm{~h}$.

(ii) Growth characteristics. Hurstbridge strains were able to grow at $13^{\circ} \mathrm{C}$ but the density of cells was less than that reached by the saprophytic reference strain Patoc $\mathrm{I}^{\mathrm{T}}$ and similar to that of strain $10^{\mathrm{T}}$ (the reference strain of $L$. inadai). Growth was partially inhibited at $30^{\circ} \mathrm{C}$ in the presence of 8-azaguanine. According to these reference tests (11), hurstbridge strains showed growth characteristics intermediate between those of pathogenic and saprophytic Leptospira strains.

(iii) Serotyping. No agglutination of hurstbridge strains was observed with any of the 26 reference antisera (7, 10). Rabbit anti-hurstbridge sera (with titres of at least 25600 ) did not agglutinate any of the 26 reference strains at the recommended dilution of $1 / 400$. There was some low-level cross-agglutination of representatives of Canicola (titre 200), Icterohaemorrhagiae (50) and Semaranga (100) serogroups. Based on these results, and according to SCT recommendations, hurstbridge strains should be considered as belonging to a new serogroup designated Hurstbridge, comprising the serovar hurstbridge.

\section{Genetic characterization}

(i) AP-PCR. Characteristic AP-PCR leptospiral fingerprints were obtained with three (KG, KF and RSP) of

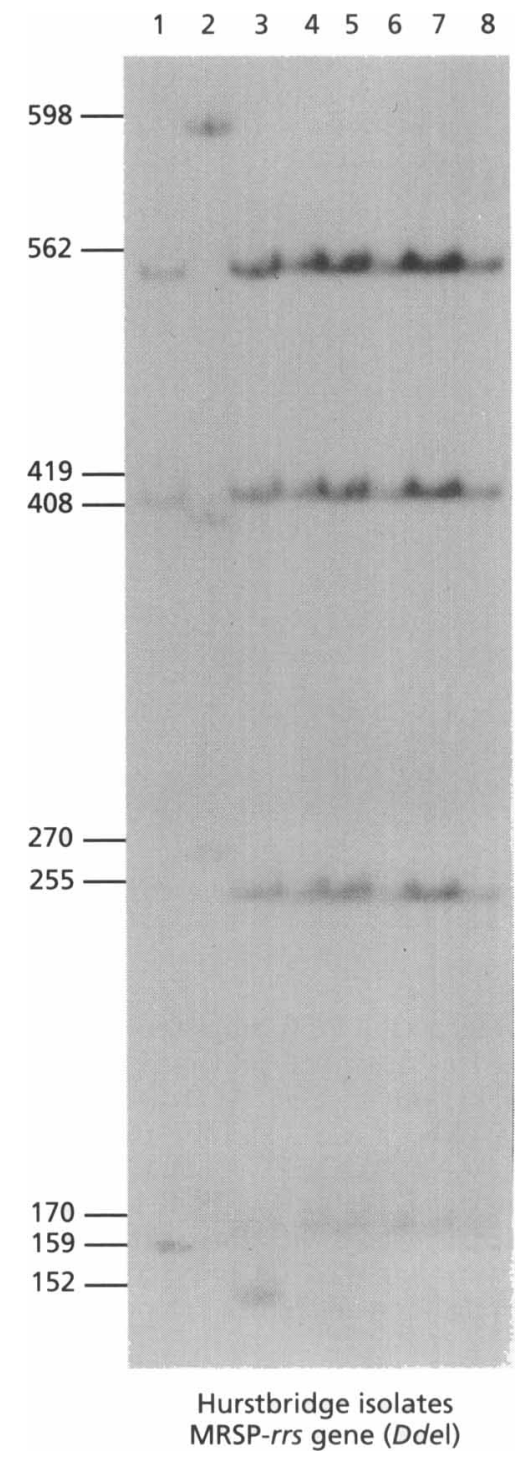

Fig. 4. Autoradiogram of Ddel restriction digests of PCRamplified 16S rRNA genes. Lanes: $1, L$. interrogans serovar icterohaemorrhagiae strain $\mathrm{RGA}^{\top} ; 2, L$. biflexa serovar patoc strain Patoc $I^{\top} ; 3$, L. inadai serovar lyme strain $10^{\top} ; 4-8, L$. fainei serovar hurstbridge strains BUT $6^{\top}$, BUT 8 , BKID 6, BKID 7 and WKID. Molecular sizes are indicated in bp.

the nine primers tested. These three primers had previously been demonstrated to produce the most useful patterns for Leptospira $(13,17)$ and representative fingerprints are shown in Fig. 2. The size of the amplified products ranged from 300 to $1000 \mathrm{bp}$. The patterns of the five hurstbridge strains were identical for a given primer. In addition, no products characteristic of the recognized Leptospira species $(14,17,18)$ were observed.

(ii) PFGE. The NotI DNA restriction patterns of the five hurstbridge strains analysed by PFGE were identical (Fig. 3) and different from those of each of the pathogenic reference strains (9). The size of restriction 
Table 1. DNA relatedness of $L$. fainei strain BUT $\sigma^{\top}$ with Leptospira species and Turneria parva reference strains $(19,24)$

Values are the percentage relative association with labelled DNA from $L$. fainei BUT $6^{\mathrm{T}}$, with the percentage relative association with labelled DNA from the corresponding species reference strain in parentheses. T, Type strain.

\begin{tabular}{|c|c|}
\hline Species & $\begin{array}{c}\text { Relative } \\
\text { association (\%) } \\
\text { with strain BUT 6 }\end{array}$ \\
\hline \multicolumn{2}{|l|}{ L. fainei } \\
\hline BUT $6^{\mathrm{T}}$ & $100 \cdot 0$ \\
\hline WKID & $100 \cdot 0(100 \cdot 0)$ \\
\hline L. interrogans $\mathrm{RGA}^{\mathrm{T}}$ & $0.0(0.0)$ \\
\hline L. borgpetersenii ATCC $43292^{\mathrm{T}}$ & $0.0(9 \cdot 0)$ \\
\hline L. inadai $10^{\mathrm{T}}$ & $34 \cdot 0(36 \cdot 0)$ \\
\hline L. kirschneri $3522 \mathrm{C}^{\mathrm{T}}$ & $2 \cdot 5(0.0)$ \\
\hline L. meyeri ATCC $43287^{\mathrm{T}}$ & $1 \cdot 0(4 \cdot 5)$ \\
\hline L. noguchii ATCC $43288^{\mathrm{T}}$ & $0 \cdot 0(7 \cdot 0)$ \\
\hline L. santarosai ATCC $43286^{\mathrm{T}}$ & $1.5(0.0)$ \\
\hline L. weilii ATCC $43285^{\mathrm{T}}$ & $0 \cdot 0(4 \cdot 0)$ \\
\hline L. biflexa Patoc $\mathrm{I}^{\mathrm{T}}$ & $0 \cdot 0(0 \cdot 0)$ \\
\hline L. wolbachii ATCC $43284^{\mathrm{T}}$ & $2 \cdot 0(1.5)$ \\
\hline Turneria parva ${ }^{\mathrm{T}}$ & $0.0(0.0)$ \\
\hline
\end{tabular}

fragments ranged from 50 to $1300 \mathrm{~kb}$ and a quadruplet in the $200-250 \mathrm{~kb}$ zone was observed only in the hurstbridge strains.

(iii) MRSP. As demonstrated previously (18), the primers $16 \mathrm{~S}-11$ and $16 \mathrm{~S}-1507$ amplified a conserved portion of the Leptospira 16S rRNA gene. PCR amplification of the $r r s$ gene of each of the hurstbridge strains produced one amplicon of the expected size $(1 \cdot 5 \mathrm{~kb})$. Restriction digestions were performed with DdeI (Fig. 4), HhaI,
HinfI and TaqI to investigate the presence of polymorphic restriction sites (18). Among the discriminating restriction sites tested with these four enzymes, the following were absent: $D d e \mathrm{I}$ in positions 80, 121 and 216; Hha I in positions 222 and 640; Hinfl in positions 198 and 974 ; and TaqI in position 826. Furthermore, an additional TaqI restriction site was present in position 792. The restriction pattern of the 16S rRNA gene (DdeI 80-, 121-, 216-; HhaI $222-, 640-$; Hinf I 198-, 974-; TaqI 792 +, 826-) was identical for each hurstbridge strain, and unrelated to the species-specific MRSP patterns previously established $(17,18)$. Therefore the hurstbridge strains appeared to represent a new species of Leptospira.

(iv) DNA-DNA hybridization. As all five hurstbridge strains appeared identical when tested by AP-PCR and PFGE, DNA-DNA hybridizations were performed between strain BUT $6^{\mathrm{T}}$, designated the reference strain for serogroup Hurstbridge and serovar hurstbridge, and pathogenic and saprophytic reference strains (Table 1). To confirm the homogeneity of hurstbridge isolates, DNA-DNA hybridizations were also performed between BUT $6^{T}$ and WKID isolates, respectively originated from two distant pig herds, in New South Wales and Victoria (Table 1). The selfDNA binding was 89 and $83.7 \%$ for strains BUT $6^{\mathrm{T}}$ and WKID, respectively.

There was no significant relatedness with any pathogenic or saprophytic species and the least distant was $L$. inadai (34 and $36 \%$ in the reciprocal tests). The homogeneity of the hurstbridge strains was confirmed by $100 \%$ relative association between BUT $6^{\mathrm{T}}$ and WKID. As the current concept of a bacterial species is one that would include strains with at least $70 \%$ DNA relatedness (23), it was concluded that the hurstbridge strains belong to a new species of Leptospira.

(v) PCR detection of pathogenic signatures on 16S rRNA genes. PCR assays on hurstbridge strains, using the

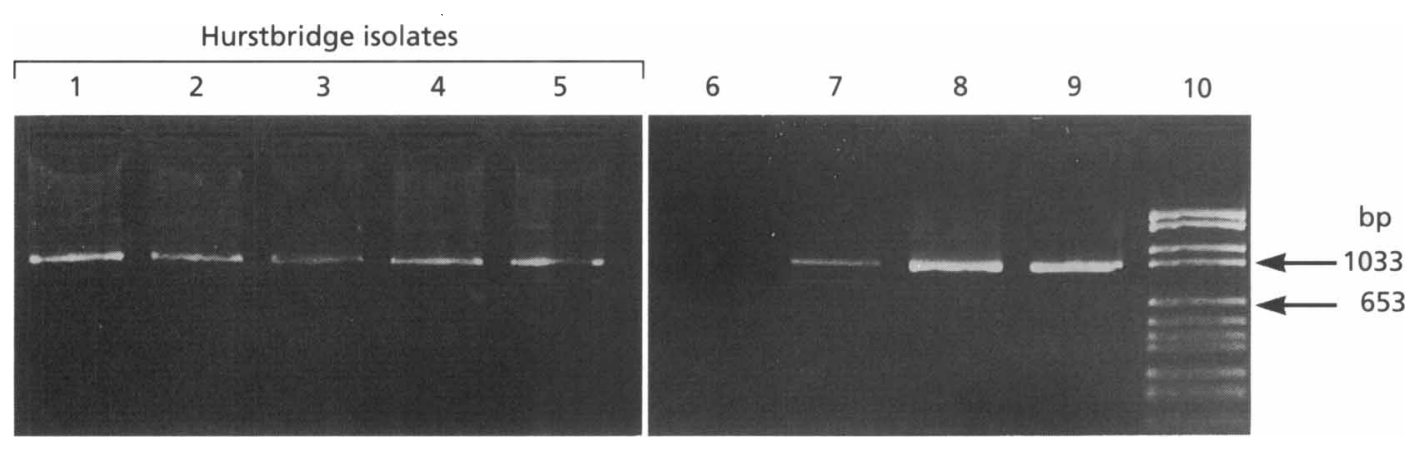

Fig. 5. PCR detection of the leptospiral pathogenic signature on the $16 \mathrm{~S}$ rRNA gene. The amplification of a $1008 \mathrm{bp} 16 \mathrm{~S}$ rRNA gene fragment was done with the primers LP1/a1190. A $2 \%$ Nusieve $3: 1$ agarose gel stained with ethidium bromide is shown. Lanes: 1-5, L. fainei serovar hurstbridge strains WKID, BKID 7, BKID 6, BUT 8 and BUT $6^{\top} ; 6, L$. biflexa serovar patoc strain Patoc $\mathrm{I}^{\top} ; 7, L$. inadai serovar lyme strain $10^{\top} ; 8$, L. interrogans serovar bratislava strain Jez-bratislava; 9. L. interrogans serovar icterohaemorrhagiae strain RGA ${ }^{\top} ; 10$, molecular mass marker (pBR328 DNA digested with Bgll + Hinfl). 


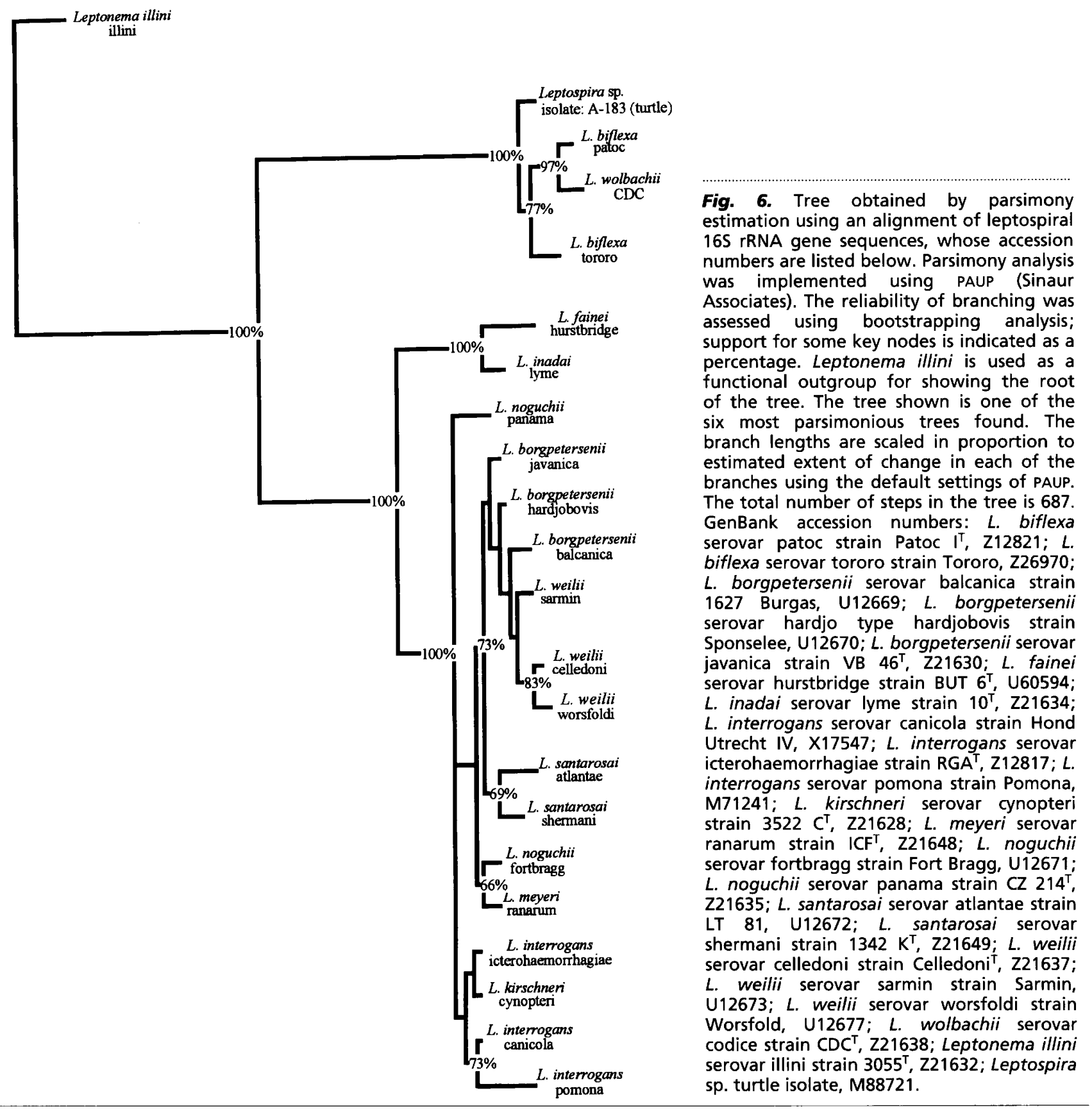

two pairs of primers (LP1/a1190 and LU/rLP) specific for pathogenic Leptospira 16S rRNA genes, produced products of the expected size: of $1008 \mathrm{bp}$ (Fig. 5) and 420 bp (data not shown), respectively.

(vi) 165 rRNA gene sequencing. A sequence of 1480 nucleotides was determined in the BUT $6^{\mathrm{T}} 16 \mathrm{~S}$ rRNA gene sequence, corresponding to positions $28-1491$ in the $E$. coli numbering system. The phylogenetic tree, including the available sequences of all the known species of Leptospira, was inferred using maximumparsimony analysis (22) and is shown in Fig. 6. Strain
BUT $6^{\mathrm{T}}$ grouped with $L$. inadai and both branched in an intermediate clade close to the clade comprising the pathogenic Leptospira. Similar trees were inferred using the unweighted pair group method with averages and the neighbour-joining method (21) (data not shown).

\section{DISCUSSION}

The five bacterial strains recovered from kidneys or uteri of sows from two geographically distant 
Australian herds had the growth and morphological characteristics of Leptospira. They were serologically unrelated to the recognized Leptospira serogroups and belong to a new serogroup designated Hurstbridge comprising the serovar hurstbridge.

Initial experiments were used to investigate whether the hurstbridge strains belonged to an existing leptospiral species. Using molecular typing methods (PFGE and AP-PCR fingerprinting), previously demonstrated as suitable for studying the genomic diversity of Leptospira, we showed that these strains appeared to be identical. MRSPs in the 16S rRNA gene were different from those in the database of reference strains of Leptospira species (19). DNA-DNA hybridizations confirmed the singularity of these isolates when they were compared with the reference strains for existing species $(19,24)$, leading to the delineation of a new species. Phylogenetic analysis based on 16S rRNA sequences showed that $L$. faine $i$ together with $L$. inadai formed a clade distinct from those containing either pathogenic or saprophytic leptospires.

\section{Description of Leptospira fainei sp. nov.}

Leptospira fainei (fain'e.i. N.L. gen. n. fainei to honour Solomon Faine, Australian medical microbiologist who made definitive contributions to the knowledge of the physiopathology and epidemiology of leptospirosis).

L. fainei grows in EMJH medium (5) at 13 and $30^{\circ} \mathrm{C}$. Under light and electron microscopy, $L$. fainei presents morphology and motility characteristic of the genus Leptospira (11). Growth at $30^{\circ} \mathrm{C}$ is partially inhibited by 8 -azaguanine $\left(225 \mu \mathrm{g} \mathrm{ml}^{-1}\right)$. L. fainei comprises one single serogroup, Hurstbridge, which is not shared with the other Leptospira species, identified by crossagglutination test according to the recommendations of the SCT (10): reference Hurstbridge antiserum only agglutinates, at a significant level (>1:400), leptospiral isolates belonging to the Hurstbridge serogroup. A unique serovar, hurstbridge, is included in this serogroup. L. fainei is characterized by its specific restriction map of the rrs (16S rRNA) gene: DdeI 80-, 121-, 216-; HhaI 222-, 640-; HinfI 198-, 974-; TaqI $792+, 826-$. TaqI $792+$ is a speciesspecific restriction site. L. fainei was isolated from genito-urinary tracts of pigs and is serologically suspected to circulate in cattle (3). The type strain BUT $6^{\mathrm{T}}$ has all the properties given for the species. It was isolated from the uterus of a sow in New South Wales (Australia) by Chappel et al. (3).

\section{ACKNOWLEDGEMENTS}

We thank Mr Chris Schroen for performing the electron microscopy and Mrs Elisabeth Bellenger, Irene Lecuyer and Vicki Vallance for technical assistance. Financial support was provided by the Pig Research and Development Corporation, Australia, the International Network of Institutes
Pasteur, the National Health and Medical Research Council, Australia, and the French Ministry of Foreign Affairs.

\section{REFERENCES}

1. Baranton, G., Postic, D., Saint Girons, I., Boerlin, P., Pifaretti, J. C., Assous, M. \& Grimont, P. A. D. (1992). Delineation of Borrelia burgdorferi sensu stricto, Borrelia garinii sp. nov., and group VS461 associated with Lyme borreliosis. Int $J$ Syst Bacteriol 42, 378-383.

2. Brenner, D. J., McWhorter, A. C., Leete Knutson, J. K. \& Steigerwalt, A. G. (1982). Escherichia vulneris: a new species of Enterobacteriaceae associated with human wounds. $J$ Clin Microbiol 15, 1133-1140.

3. Chappel, R. J., Billinghurst, M. L., Adler, B., Bulach, D. M., Khalik, D., Merien, F., Serrano, M. S., Wilson, R. J. \& Perolat, P. (1996). Isolation from pigs of a pathogenic leptospire of a new genospecies and serogroup (serovar hurstbridge), and a serological study of its distribution and possible veterinary significance. Proceedings of the First Meeting of the International Leptospirosis Society, Nantes.

4. Dikken, H. \& Kmety, E. (1978). Serological typing methods of leptospires. Methods Microbiol 11, 259-307.

5. Ellinghausen, H. C. \& McCullough, W. G. (1965). Nutrition of Leptospira pomona and growth of 13 other serotypes: fractionation of oleic albumin complex and a medium of bovine albumin and polysorbate 80. Am J Vet Res 26, $45-51$.

6. Ellis, W. A., Montgomery, J. M. \& Thiermann, A. B. (1991). Restriction endonuclease analysis as a taxonomic tool in the study of pig isolates belonging to the Australis serogroup of Leptospira interrogans. J Clin Microbiol 29, 957-961.

7. Faine, S. (1982). Guidelines for leptospirosis control. Geneva: World Health Organization.

8. Grimont, P. A. D., Popoff, M. Y., Grimont, F., Coynault, C. \& Lemelin, M. (1980). Reproducibility and correlation study of three deoxyribonucleic acid hybridization procedures. $C u r r$ Microbiol 4, 326-330.

9. Herrmann, J. L., Bellenger, E., Perolat, P., Baranton, G. \& Saint Girons, I. (1992). Pulsed-field gel electrophoresis of NotI digests of leptospiral DNA : a new rapid method of serovar identification. J Clin Microbiol 30, 1696-1702.

10. International Committee on Systematic Bacteriology Subcommittee on the Taxonomy of Leptospira (1987). Minutes of the Meeting, 5 and 6 September 1986, Manchester, UK. Int J Syst Bacteriol 37, 472-473.

11. Johnson, R. C. \& Faine, S. (1984). Family II. Leptospiraceae. Hovind-Hougen 1979, 245 ${ }^{\mathrm{AL}}$. In Bergey's Manual of Systematic Bacteriology, vol. 1, pp. 62-67. Edited by N. R. Krieg \& J. G. Holt. Baltimore: Williams \& Wilkins.

12. Johnson, R. C. \& Rogers, P. (1964). Differentiation of pathogenic and saprophytic leptospires with 8-azaguanine. $J$ Bacteriol 88, 1618-1623.

13. Kmety, E. \& Dikken, H. (1993). Classification of the Species Leptospira interrogans and History of its Serovars. Groningen: University Press.

14. Letocart, M., Baranton, G. \& Perolat, P. (1997). Rapid identification of pathogenic Leptospira species $(L$. interrogans, L. borgpetersenii, and L. kirschneri) with species-specific probes produced by arbitrarily primed PCR. $J$ Clin Microbiol 35, 248-253. 
15. Marchuk, D., Drumm, M., Saulino, A. \& Collins, F. S. (1991). Construction of T-vectors, a rapid general system for the direct cloning of unmodified DNA products. Nucleic Acids Res 19, 1154.

16. Perolat, P., Lecuyer, I., Postic, D. \& Baranton, G. (1993). Diversity of ribosomal DNA fingerprints of Leptospira serovars provides a database for subtyping and species assignation. Res Microbiol 144, 5-15.

17. Perolat, P., Merien, F., Ellis, W. A. \& Baranton, G. (1994). Characterization of Leptospira isolates from serovar hardjo by ribotyping, arbitrarily-primed PCR, and mapped restriction site polymorphisms. J Clin Microbiol 32, 1949-1957.

18. Ralph, D., McClelland, M., Welsh, J., Baranton, G. \& Perolat, P. (1993). Leptospira species categorized by arbitrarilyprimed polymerase chain reaction (PCR) and by mapped restriction polymorphisms in PCR-amplified rRNA genes. $J$ Bacteriol 175, 973-981.

19. Ramadass, P., Jarvis, B. D. W., Corner, R. J., Penny, D. \& Marshall, R. B. (1992). Genetic characterization of pathogenic Leptospira species by DNA hybridization. Int J Syst Bacteriol 42, 215-219.

20. Ruimy, R., Breittmayer, V., Elbaze, P., Lafay, B., Boussemart, O., Gauthier, M. \& Christen, R. (1994). Phylogenetic analysis and assessment of the genera Vibrio, Protobacterium, Aeromonas, and Plesiomonas deduced from small-subunit rRNA sequences. Int $J$ Syst Bacteriol 44, 416-426.

21. Saitou, N. \& Nei, M. (1987). The neighbor-joining method: a new method for reconstructing phylogenetic trees. Mol Biol Evol 4, 406-425.

22. Swofford, D. L. (1991). PAUP: phylogenetic analysis using parsimony, version 3.0. Illinois Natural History Survey, Champaign, IL, USA.

23. Wayne, L. G., Brenner, D. J., Colwell, R. R. \& 9 other authors (1987). International Committee on Systematic Bacteriology. Report of the ad hoc committee on reconciliation of approaches to bacterial systematics. Int J Syst Bacteriol 37, 407-415.

24. Yasuda, P. H., Steigerwalt, A. G., Sulzer, K. R., Kaufmann, A. F., Rogers, F. \& Brenner, D. J. (1987). Deoxyribonucleic acid relatedness between serogroups and serovars in the family Leptospiraceae with proposals for seven new Leptospira species. Int J Syst Bacteriol 37, 407-415.

25. Zuerner, R. L. \& Bolin, C. A. (1990). Nucleic acid probe characterizes Leptospira interrogans serovars by restriction fragment length polymorphisms. Vet Microbiol 24, $355-366$. 